Katerina Malygina

\title{
Ukraine as a neo-patrimonial state: understanding political change in Ukraine in 2005-2010
}

\begin{abstract}
After the Orange Revolution, it was supposed by many that the change to liberallyminded, western-oriented leaders and the reduction of the presidential powers would be sufficient to guarantee Ukraine's transition to democracy. However, this proved to be wrong. A change of institutional design in Ukraine led indeed to less authoritarianism, as well as to free and fair elections and freedom of speech. But, as the post-revolutionary experience has shown - informal rules do matter in Ukraine. The formal framework only limits the scope of action, but the actors are not guided in their behaviour exceptionally by the formal rules. Thus, Ukraine was and remains a neo-patrimonial state, with both formal and informal logics of action. In order fully to understand the political change in Ukraine after the Orange Revolution, one should not limit the whole explanatory strength solely to the formal institutions. The model proposed in this article, consisting of such variables as formal and informal resources as well as actors' expectations, should help in understanding the scope of political change in Ukraine since 2005.
\end{abstract}

Keywords: Ukraine, political change, neo-patrimonial state, rule by law, Orange Revolution

Introduction

One of the main results of the Orange Revolution was the change of the institutional design, as agreed between Orange and anti-Orange forces in December 2004. The constitutional changes that entered into force in 2006 devolved some presidential powers to Parliament (Verkhovna Rada), most importantly the right to appoint the Prime Minister and the Cabinet. With such broad powers of appointment, Parliament gained more incentives for coalition-building. The latter became obligatory and its procedure was highly formalised in the amended Constitution. However, the new status of Parliament did not serve it well from the point of its functionality; in the last five years, it has remained paralysed most of the time. The Verkhovna Rada turned into an individual player on the political scene that challenged the President, and also often the government, and fought with them both for power.

Anticipating these changes, power struggles between the different actors had already started in 2005. In September 2005, less than one year after the Orange Revolution, the government of Yulia Tymoshenko was sacked. With the help of the Party of the Regions and its leader Viktor Yanukovich, the pro-presidential Yuriy Yehanurov was appointed the new Prime Minister. 
In March 2006, parliamentary elections took place. The Party of the Regions received most of the votes, but not an absolute majority. Orange forces trumpeted that they would unite again, but could not agree on forming a coalition. Unexpectedly, the non-Orange coalition, consisting of the Party of the Regions, the Social Party of Ukraine and the Communist Party of Ukraine, was formed in August 2006. This secured the victorious comeback of Viktor Yanukovich as Prime Minister.

Two political struggles then followed. Autumn/winter 2006-2007 was marked by the war of 'Prime Minister Viktor Yanukovich against President Viktor Yushchenko'. Over a period of seven months, Yanukovich systematically undermined Yushchenko's position, trying to curtail his formal powers. In March 2007, his coalition started to grow as a result of deputies defecting from other parties. There was a threat that the ruling coalition might obtain the necessary 300 votes to change the Constitution away from the President. This was the turning point and the war 'Yushchenko against the Yanukovich coalition' then followed. In early April 2007, Yushchenko issued a decree to dissolve Parliament, although it clearly did not fall under any of the three provisions in the Constitution that granted the President such a right. The Verkhovna Rada refused to obey the presidential decree and two months of strong confrontation followed, culminating on 24-25 May when the armed forces were involved in the conflict.

Only after that did all the parties settle down to negotiations, reaching agreement to dissolve Parliament and call for early parliamentary elections in September 2007. The result of these elections was that, in December 2007, a new Orange coalition was formed between the pro-presidential bloc 'Our Ukraine-Self Defence' (NUNS) and Bloc Yulia Tymoshenko (BYuT). Tymoshenko was appointed Prime Minister for the second time.

Even so, the political crises were not over. In September 2008, the coalition of the Orange forces fell apart after the pro-presidential NUNS withdrew from it. The reason was an alleged agreement reached between the Party of the Regions and BYuT to change the Constitution. Yushchenko tried again to dissolve Parliament, which was once more legally dubious since the Constitution forbids the dissolution of Parliament in two successive years. The result was that the Verkhovna Rada was once again paralysed. However, it acted cohesively when the situational interests of the actors intersected, as in the case of the adoption of the so-called 'anti-crises law' required to trigger the loan from the International Monetary Fund, or the dismissal of the parliamentary speaker. In December 2008, Tymoshenko announced the formation of a new coalition between NUNS, BYuT and 'Bloc Lytvyn'.

The following year, in 2009, the country was struggling to overcome the global economic crises that hit Ukraine hard in the autumn of 2008 . However, the attempts were not really successful - Ukraine's GDP dropped $15 \%$ in 2009. The year was also marked by preparations for the upcoming presidential elections.

So, this is the inner-political balance and a short summary of 'Orange' Ukraine in the Yushchenko era: it was marked by unending political crises but also political pluralism, and free and fair elections as well as free media. These four factors contributed largely to the fully democratic victory of Viktor Yanukovich in the presidential elections in February 2010. Yet the Yanukovich era started with a swift consolidation of 
power, a diminishing of the role of Parliament, a curtailing of freedom of speech and harassment of the opposition. ${ }^{1}$

How could it have happened that Ukraine, seen by many as moving towards democracy, had swung back again to authoritarianism? Democratisation studies failed to foresee the rise of authoritarian tendencies in Ukraine in 2010. Their conceptual lens limited the explanation of the many non-democratic practices of 'Orange' Ukraine vis$\grave{a}$-vis the difficulties on the road towards, rather than away from, democracy. In 2002, Carothers had proclaimed 'the end of the transition paradigm'. His concept of 'feckless pluralism' makes a good contribution towards explaining political change in Ukraine since 2005. According to Carothers, feckless pluralism is marked by:

Significant amounts of political freedom, regular elections and the alternation of power between genuinely different political groupings,

but where politicians are seen as corrupt and self-interested, and cut off from the people (Carothers, 2002: 10-11). Yet feckless pluralism pays great attention to formal institutions and says nothing about informal practices (Zimmer, 2008: 276). In Ukraine, informal rules co-exist beside formal ones, so the concept of feckless pluralism explains only to a limited extent the nature of the political changes in this country.

This article applies a different analytical framework. The inner-political change in Ukraine in 2005-2010 will be analysed from the point of view that Ukraine was - and remains - a neo-patrimonial state with a lack of private-public differentiation and an appropriate mix of formal and informal logic towards action. Thus, the article is structured as follows. Firstly, the concept of the neo-patrimonial state will be introduced and its basic features identified. The next section presents an overview of the studies that analysed Ukraine before 2004, highlighting the perspective that President Leonid Kuchma's regime was neo-patrimonial. Afterwards, the neo-patrimonial character of Ukraine after 2005 will be proved with the help of a consistent consideration of the main features inherent to the neo-patrimonial state singled out in the first section. The last section provides a model that should help in understanding the political changes taking place in Ukraine since 2005.

\section{Analytical framework: the concept of the 'neo-patrimonial state'}

The term 'neo-patrimonialism' refers back to Weber's term 'patrimonialism', which he used to delineate the type of authority and the source of legitimacy. According to Weber (1978: 231), patrimonialism:

Tends to arise whenever traditional domination develops an administration and a military force which are purely personal instruments of the master.

This type of authority Weber saw as in opposition to rational-legal authority, with the latter characterised by an impersonal bureaucratic logic grounded in the rule of law

1 On the first one hundred days of the Yanukovich Presidency, see, for instance, Lange (2010). 
(Pitcher, et al.2009: 130). Based on a mix of these two ideal authority types, the concept of neo-patrimonialism was developed for the analysis of developing countries - in Africa, in the first instance (Erdmann and Engel, 2006: 7ff).

A neo-patrimonial state is understood as a patrimonial-bureaucratic state, ${ }^{2}$ in which informal (patrimonial) and formal (bureaucratic) logics of action co-exist. The main feature of neo-patrimonialism is the private appropriation of the public realm. Public and private spheres are de jure separated, but de facto such differentiation does not exist. The consequence is that state officials often use public resources for the particularist purposes of acquiring personal wealth and status (Bratton and van de Walle, 1994: 458). Corruption ${ }^{3}$ is therefore endemic. Compliance with the formal rules, but also their circumvention, is a usual practice. However, the more the formal rules are disregarded, the greater is the tendency to rely on patrimonial practices (Hensell, 2009: 59). These help to stabilise the system in the following way.

The result of a certain leeway in actors' behaviour, which may allow a choice between formal and informal logics of action, is that there is always a certain level of insecurity with regard to the actors' choice (Zimmer, 2008: 277; Erdmann and Engel, 2006: 21). To reduce this uncertainty, the actors decide to maintain authority via loyalties and personal dependencies rather than formal institutions. There are two kinds of loyalties inherent to neo-patrimonialism - political clientelism and patronage. ${ }^{4}$ Both forms present an exchange of specific services or resources for political support. According to the differentiation made by Erdmann and Engel (2006: 21), clientelism implies individual political support for individual benefit (e.g. jobs for votes); while patronage implies the political support of groups for collective benefits (e.g. roads, schools etc.). In a neo-patrimonial state, clientelism is the predominant mode of recruitment into public administration (Hensell, 2009: 123), based not on the principles of professionalism and qualifications, but on the criterion of personal expectations of loyalty. Patronage networks usually exist at the intersection of different formal institutions, as well as that of the state and the economy. They thus link Parliament, political parties, the media, economic actors, etc. (Zimmer, 2008).

Belonging to a patronage network means both personal gains and protection against the unpredictable behaviour of public institutions (Erdmann and Engel, 2006: 21). The result is that a neo-patrimonial state becomes, in O'Donnell's phrase (1996: 39), ${ }^{5}$ 'informally institutionalised'. Informal institutionalisation does not imply that informal rules dominate formal ones. The relationship between formal and informal rules is still

2 For the elaboration of the concept 'bureaucratic-patrimonial state', see Hensell (2009: 122ff).

3 Defined by Transparency International as the 'abuse of entrusted power for private gain' http:// www.transparency.org/about_us [last accessed on 12 June 2010].

4 As pointed out by Erdmann and Engel (2006), some scholars treat clientelism and neo-patrimonialism as competing models.

5 O'Donnell calls countries that are consolidated democracies formally institutionalised countries; and unconsolidated ones informally institutionalised. However, he admits that such a differentiation is not perfect because 'in the first set of countries, many things happen outside formally prescribed institutional rules, while the second set includes one highly formalised institution, elections' (O’Donnell, 1996: [Fn. 2]). 
disputable among scholars ${ }^{6}$ and, presumably, varies between countries. In our understanding, it means that neo-patrimonial relations are, on the one hand, widely accepted and constitute voluntary compliance with a system, in this way legitimating it. On the other hand, they operate as behavioural instructions in an otherwise highly uncertain environment. In 'formally institutionalised' countries that are consolidated democracies, on the contrary, the level of uncertainty is reduced by a behavioural compliance of all actors with formal rules and institutions (Przeworski, 1991: 26).

The consequence of informal institutionalisation is a lack of horizontal accountability (O'Donnell, 1996: 43-44). In formally institutionalised, consolidated democracies, formal institutions have clearly defined and legally-established boundaries to their authority. There are also state institutions that are empowered to check and punish abuses by other public agencies. In neo-patrimonial states, the boundaries between private and public are blurred and formal rules are binding only to some extent, so the judiciary does not properly perform its function of horizontal checks. Just as with other state bodies, courts are privatised and instrumentalised to meet the interests of different actors and law becomes a commodity that can be purchased. In addition, selective law enforcement could be used to manage patronage networks, by punishing disloyal, or insufficiently loyal, people and by ignoring violations of associates. ${ }^{7}$ The result is not the 'rule of law' but rather 'rule by law' (Zimmer, 2008: 282; D'Anieri, 2007: 50). Contradictory laws or legislation with loopholes play an important role here. 'Rule by law' is thus a mixture of formal procedures and informal strategies that runs in line with the logic of a neo-patrimonial state (Zimmer, 2008: 281).

In conclusion, the neo-patrimonial state is characterised first by the co-existence of formal and informal logics of action; and, second, by a set of social relations that include patron-client relationships, corruption and 'rule by law'.

\section{The neo-patrimonial regime under Kuchma}

The concept of 'neo-patrimonialism' has been actively used in the analysis of African states. Recently, however, a growing number of scholars have begun to apply it to post-communist countries, especially with respect to central Asia (Fisun, 2007; Hensell, 2009; Starr, 2006; Franke et al. 2009; Ilkhamov, 2007; Isaacs, 2010). Among authors that refer to Ukraine as a neo-patrimonial state are Hale (2005, 2006), Zimmer $(2005,2008)$ and Fisun (2007). Not calling Ukraine explicitly 'neo-patrimonial', a number of authors otherwise pay special attention to regional networks and oligarchic clans (Pleines, 2005; Kusznir and Pleines, 2006; Kowall and Zimmer, 2002; Puglisi, 2003, 2008; Melnykovska and Schweickert, 2008). In most of these studies, the term 'neo-patrimonial' is used to describe the political regime under the second President of Ukraine, Leonid Kuchma. In the following, Kuchma's regime will be depicted based on these studies.

6 For instance, there are three different assumptions as to the relationship between formal and informal rules: informal rules replace formal rules; informal rules work alongside formal rules; and formal and informal rules are blurred. See Zimmer (2008: 267).

7 On selective law enforcement as a strategy of power politics in Ukraine under Kuchma, see D’Anieri (2006:193ff). 
The emergence of neo-patrimonialism (as a set of social relationships) in the independent Ukraine is connected with the Soviet legacy (Zimmer, 2008) and is therefore deeply embedded in its political culture. According to Fisun (2007), new forms of neopatrimonial regimes emerged in most post-Soviet states after the collapse of the Soviet Union. In those countries, where a charismatic president set personal control over politics and business, sultanistic regimes were formed (Azerbaijan, Kazakhstan, Uzbekistan, Kyrgyzstan, Turkmenistan, Belarus). 'State capture' by rent-seeking economic players, in alliance with the neo-patrimonial bureaucracy, led to the establishment of oligarchic-patrimonial regimes (Russia, Ukraine, Moldova, Georgia, Armenia).

However, in the first half of the 2000s, the most influential economic actors began to demand the introduction of new rules of the game aimed at cutting down the role of the president. The result was that two rational-bureaucratic transformations took place - 'political rationalisation' from the bottom (through 'colour revolutions'); and 'power rationalisation' from the top (through 'bureaucratic revolution'). The 'power rationalisation' led to the creation of a third form of neo-patrimonial regime in the post-Soviet space - 'bureaucratic neo-patrimonialism' - in which the 'power' bureaucracy dominates such as, for instance, in Russia since the presidency of Putin. ${ }^{8}$

According to Fisun's classification introduced above, Ukraine was transformed into a typical oligarchic-patrimonial regime during Kuchma's second term in office (1999-2004). The main feature of such a regime is the rise of powerful rent-seeking economic actors (oligarchs) who operate alongside, or in place of, state institutions through patronage networks (Fisun, 2007). These patronage networks developed in Ukraine across regional lines. Different authors distinguish between the Kyiv, the Dnepropetrovsk and the Doneck clans, ${ }^{9}$ each being dominated by different oligarchs (Kusznir and Pleines, 2006; Kowall and Zimmer, 2002; Puglisi, 2003). Closeness to the President was important because that meant access to state financial and administrative resources. In order to maintain control over these networks and to prevent the rise of possible competitors, Kuchma used a 'divide and rule' strategy that consisted of the regular dismissal and appointment of high-level officials. By constantly redistributing the power between the different actors that competed with each other for the presidential beneficence, Kuchma managed to create a powerful centre for his personal rulership (Puglisi, 2003: 103; Pleines, 2005: 86-87). Therefore, the stability of such a regime was highly dependent on Kuchma himself.

A somewhat different depiction of Kuchma's regime was suggested by Hale (2005, 2006). Building on theories of patrimonialism and presidentialism, Hale proposed to name the regime inherent to Ukraine under Kuchma as 'patronal presidentialism'. Like Fisun, he acknowledges that this type of regime was:

A product of the post-communist transition itself, although the general importance of informal networks and authority was a holdover from the Soviet period. (Hale 2006: 307)

8 Fisun, however, does not go deeper into questioning what happened to those regimes where 'political rationalisation' through coloured revolutions took place.

9 For a detailed study of the Doneck clan, see Zimmer (2006). 
Hale defines patronal presidentialism by two main components:

First, a directly elected presidency is invested with great formal powers relative to other state organs. Second, the president also wields a high degree of informal power based on widespread patron-client relationships at the intersection of the state and the economy. The term 'patronal' thus refers to the exercise of political authority primarily through selective transfers of resources rather than formalized institutional practices, idea-based politics, or generalized exchange as enforced through the established rule of law. (Hale, 2005: 137-138)

The following conclusions could be drawn from such a definition of 'patronal presidentialism'. First, Hale admits that informal practices dominate formal rules. Second, instead of using the term 'patrimonial' or 'neo-patrimonial', he uses the term 'patronal'. Hale himself explains that this choice of terminology is due to purely patronal networks being more dynamic than patrimonial ones, in which authority is build not only on material exchange but also on strong attachments rooted in kinship, territory or tradition (Hale, 2005: 138 [Ref. 15]). Thereby, Hale ignores the regional rootedness of the informal networks in Ukraine which are underlined by other authors.

Analysing the relationship between the president and other elites, Hale points out to their mutual dependence:

The president depends on elites for implementing decisions and delivering votes while elites depend on the president for resources and/or continuation in their posts. (Hale, 2005: 138)

Subsequently, he concludes that a patronal president is in a better position than the elites because he possesses the administrative resources with which he may divide and rule the elites.

This leads us again to two further conclusions. First, in Hale's analysis emphasis is laid on the institute of the presidency and not on the personal rule of the president or his leadership style, as in other studies. Second, formal powers shape the informal powers of the president.

In conclusion, both approaches that depict the regime under Kuchma - patronal presidentialism and oligarchic-patrimonialism - put different emphases on the role of agents: patronal presidentialism pays much attention to the formal status of the president, which allows him vast informal powers, while the oligarchic-patrimonial approach concentrates more on the oligarchs as the result of the informal side of the regime. The common features to both approaches are, firstly, the role of a ruler who uses a divide and rule strategy to prevent any opposition from emerging; and, secondly, political contestation as an elite affair where powerful groups compete over state control. Similar features could be found in the depiction of neo-patrimonial states in Africa (see, for example, Bratton and van de Walle, 1994). This leads us to the conclusion that the regime under Kuchma was truly neo-patrimonial. 


\section{Neo-patrimonial character of Ukraine after the Orange Revolution}

Kuchma's neo-patrimonial regime was overthrown by the Orange Revolution, but social relations in Ukraine stayed, at their root, neo-patrimonial. Ukrainian politicians are guided in their actions both by formal and informal logics; on the surface trying to adhere to the former, but applying the latter if formal logic fails to bring about the expected outcome.

In the following, the neo-patrimonial character of Ukraine will be proven with the help of a consistent consideration of the key features inherent to a bureaucratic-patrimonial state which were singled out in the first section of this article. These are:

- patron-client relationships

- corruption

- the 'rule by law'.

\section{Patron-client relationships}

In spring 2005, the Ukrainian journalist Julia Mostova ironically noted that Kuchmism under Kuchma was replaced by Kumism under Yushchenko, a term understood as the dominance of the godparents (kum means godfather) (cited in Templin, 2008: 166). Among the famous godfathers of the Yushchenko children are such oligarchs as David Zhvania and Petro Poroshenko. Immediately after the Orange Revolution, the first was appointed Minister for Emergency Affairs; while the second became the Secretary of the National Defence and Security Council. Yushchenko's older brother Petro Jutschenko is a member of the parliamentary faction 'Our Ukraine-National Defence' (NUNS) and is a successful businessman. Mikhail Doroshenko, Yushchenko's old friend from his birthplace, Khoruzhivka, served as adviser to the President.

Viktor Yushchenko was accused of appointing his lyubi druzi (dear friends $)^{10}$ to key positions, but the level of cronyism under the new President Viktor Yanukovich is said to be even more: relatives of at least forty people from the President's inner circle occupy positions in different state bodies, courts or are local level representatives in the Verkhovna Rada. ${ }^{11}$ All together, they form a network of about one hundred people. Yanukovich's own son, Viktor Yanukovich Jr, is a representative in the Verkhovna Rada from the Party of Regions, elected after the parliamentary elections of 2006. Not surprisingly, the new Ukrainian government, appointed by Parliament on 11 March 2010, has the largest number of ministers in Europe - 29 - and the second largest, after Russia, in terms of the number of vice-premiers $-7 .^{12}$

Politicians bring their closest friends and relatives into politics, so politics becomes extremely personalised. It also creates large patronage networks in a broad sense. In

10 A phrase that Yushchenko used to open his speeches. Ukrainian journalists quickly picked it up to define the inner circle of the President.

11 Korrespondent: 'Janukovich i ego komanda prevratili vlast' v semejnoe delo' 18 June 2010, available at: http://korrespondent.net/ukraine/politics/1087646 [last accessed on 22 June 2010].

12 Ukrainska Pravda: 'Kabmin Azarova pobil evropejskie rekordy' 14 March 2010, available at: http://www.pravda.com.ua/rus/news/2010/03/14/4862321/ [last accessed on 22 June 2010]. 
the Ukrainian mass-media, it has even become popular to visualise and analyse the socalled satellites of the political leaders. In principle, Ukrainian law permits such appointments, prohibiting them only in one case - where people are in direct subordination to their relatives and close friends. ${ }^{13}$ Moreover, the shift to an electoral system in Ukraine in which, since 2006, nominations have been fully based on party lists has further strengthened the link between parties and elected representatives and has, as a result, promoted cronyism in Parliament.

Unfortunately, there are almost no detailed studies on patronage networks in Ukraine, especially after the Orange Revolution. In 2008, a group of economists (Baum et al, 2008) tried to identify 'grey' links between commercial banks and Ukrainian parliamentary deputies; their goal was to investigate whether banks with political connections behave differently from those lacking them. The result of the study was positive - i.e. that:

The activity of affiliated politicians negatively influences banks' interest rate margins and positively influences their capitalization ratios. (Baum et al: 19)

\section{Corruption}

The Corruption Perception Index of Transparency International (CPI) shows that Ukraine is perceived as one of the most corrupt countries in the world. In 2009, it was ranked 146 among 180 states. ${ }^{14}$ Moreover, its position in the CPI has deteriorated in comparison to other 'Orange' years: in 2006, Ukraine had been placed 64th from the end compared to 2009's 34th. Thus, the position on the corruption scale, by the end of Yushchenko's term in office, neared that under Kuchma, when Ukraine was placed $23^{\text {rd }}$ from the end. Parliament is seen as the most corrupt institution in Ukraine, followed by the judiciary and the law enforcement agencies, the latter both at the local level. ${ }^{15}$

The Yushchenko era will be remembered for myriad high-profile corruption scandals. The goal of these scandals was often to discredit the opponent and 'improve' one's own position. Some of these scandals were part of the Yushchenko-Tymoshenko wars. For instance:

- in September 2005 the former Head of the Presidential Secretariat, Oleksandr Zinchenko, accused the President's inner circle of corruption. The scandal ended with the resignation of the Tymoshenko government, as well as the collapse of the pro-presidential coalition

- in October 2008, Tymoshenko accused Volodymyr Stelmakh, the Head of the National Bank of Ukraine, of currency speculation and the President, Viktor

13 Article 12 of the Law on the Civil Service, available at: http://zakon.rada.gov.ua/cgi-bin/laws/ main.cgi?nreg=3723-12 [last accessed on 22 June 2010].

14 Corruption Perceptions Index 2009, available at: http://www.transparency.org/policy_research/surveys_indices/cpi/2009/cpi_2009_table [last accessed on 23 June 2010].

15 See expert opinion poll: 'How spread is political corruption in each of the following bodies (institutes) of power and political institutes?' (Razumkov Centre, 2009: 44). Note - the values of the indicators 'Corruption permeates everything' and 'Corruption is rather widespread' are added. 
Yushchenko, of covering them up. In return, Yushchenko accused Tymoshenko of manipulation of land auctions.

Other corruption scandals surrounded the lobbying of corporate and private interests by high-ranking officials:

- in 2005, Tymoshenko's government was accused of lobbying for the Pryvat group, ${ }^{16}$ which was interested in the re-privatisation of the Nikopol Ferroalloy Factory (Razumkov Centre, 2009: 28) ${ }^{17}$

- in May 2008, President Viktor Yushchenko was accused by Tymoshenko of lobbying on behalf of the interests of the US-based Vanco International Ltd, which won the bid for the development of the oil and gas deposits on the Black Sea shelf. ${ }^{18}$ On 21 May 2008, the Cabinet of Ministers decided to revoke and terminate this contract.

There were also several corruption scandals concerning the falsification of university diplomas, such as that involving Roman Zvarych, Minister of Justice, in April 2005, ${ }^{19}$ and Andriy Kyslynskyi, Deputy Head of the Presidential Secretariat, in October $2008 .{ }^{20}$ Interestingly, Zvarych was not dismissed from his post for his fraud, whereas Kyslynskyi was dismissed. In August 2008, before the corruption scandal, it was Kyslynskyi who had accused Prime Minister Yulia Tymoshenko of treason and of holding secret negotiations with Moscow.

This list of corruption scandals is by no means comprehensive; there are also plenty of cases that do not receive publicity. During Yushchenko's incumbency, not one of the publicly-accused corrupt officials was ever convicted of misdeeds. The new President of Ukraine, Viktor Yanukovich, who took office in February 2010, continued the 'tradition' of the accusation of his opponents of public corruption. In March 2010, he launched an international audit to check the country's budget and IMF loan spending under the Tymoshenko government between 2008 and 2010. However, the opposition claimed immediately that the audit was custom-ordered and that the hired American firm was not even an audit company but one that specialised in litigation. ${ }^{21}$

Under Kuchma, the widely-spread corruption was used as an instrument of control and power. Darden (2001) describes it in terms of the Ukraine functioning as a 'black-

16 The Dnepropetrovsk-based Pryvat group is owned by the oligarch Ihor Kolomoiskyi. It has business interests in oil refining, metal industry and finance (Pleines, 2009: 106). During the Orange Revolution, the Pryvat group supported Viktor Yushchenko and his allies.

17 The court recognised the illegality of the previous privatisation, but nationalisation of the enterprise was avoided by an implicit pact between the Pryvat group and Rinat Akhmetov, who had owned the factory since May 2003.

18 Ukrainska Pravda: 'Sprava Vanco: novij korupcijnij skandal?' 13 June 2008, available at: http://www.pravda.com.ua/articles/2008/05/13/3435517/ [last accessed on 22 June 2010].

19 Ukrainska Pravda: 'Ministr Zvarich - shche odyn proFFesor?' 14 April 2005, available at: http://www.pravda.com.ua/articles/2005/04/14/3008832/ [last accessed on 22 June 2010].

20 Ukrainska Pravda: 'Jushchenko zvil'nyv bezdyplomnyka' 13 October 2009, available at: http://www.pravda.com.ua/news/2009/10/13/4237733/ [last accessed on 22 June 2010].

21 Hryhoriy Nemyria: 'Audit ordered by Azarov is a tool for persecuting the opposition' 19 May 2010, available at: http://www.tymoshenko.ua/en/article/8nev2veo [last accessed on 22 June 2010]. 
mail state' that not only tolerated corrupt behaviour, but even encouraged it. At the same time, the powerful state surveillance apparatus collected information on all illegal activities, which it later used to threaten disloyal people with lawsuits. The corruption scale hardly changed after the Orange Revolution, so there is no reason to believe that this practice had disappeared. Yet under Yushchenko, the instrumentalisation of corruption acquired some new features: corruption charges became public and were often a pretext for public parliamentary and/or criminal investigation, with the aim of dismissing the obstructing person (e.g. the Minister of Foreign Affairs and Minister of Defence in September 2006; the Judge of the Constitutional Court in April 2007). The instrumentalisation of corruption is thus closely connected with another neo-patrimonial practice - rule by law.

Lack of the 'rule of law' and the 'rule by law'

Ukrainian politics is characterised by a:

... highly utilitarian and manipulative approach towards constitution-making and legislation in general. (Bredies, 2009: 39)

Many laws have loopholes and contradictory clauses that allow different actors to interpret them to their own liking. Such an approach to formal rules could be named as 'rule by law'.

The Constitution in Ukraine was never accepted as a binding framework and the institutional status quo was, from time to time, challenged (Simon, 2009: 17). However, the actors' preferences are highly inconsistent and depend largely on the current situation (Bredies, 2009: 28; Lange, 2009: 2). For instance, when Leonid Kuchma was President, he pressed for an expansion of the presidential powers at the expense of those of Parliament. Yet, following 2002, Kuchma changed his position radically, now advocating a shift in powers in favour of Parliament, hoping in this way to become Prime Minister after his second term in office (Bredies, 2009: 31-32).

Also in the post-revolutionary Ukraine, various actors tried to change the Constitution in their favour. Having supported amendments to the Constitution in 2004, Yushchenko won the presidency. However, immediately after the inauguration, he began to insist on the need for a strong presidential power. In 2006, the President tried to appeal to the Constitutional Court with the aim of undoing the constitutional amendments. He failed to do so, but instead created a constitutional commission to draft a new constitution by the end of 2007. Its draft, proposed for public discussion in March 2009, saw a renewed increase in the presidential powers and also the introduction of a second chamber of parliament (Bos, 2010: 81-82).

The leading political parties, on the contrary, advocated an increase in the rights of Parliament. In this direction, BYuT and the Party of the Regions attempted several times to unite in 2008-2009. In 2008, this process was disrupted by the withdrawal of the pro-presidential faction NUNS from the Orange coalition, which led to another political crisis. In June 2009, the common constitutional draft of the Party of the Regions and BYuT was leaked to the media. It envisaged a parliamentary system of government and the election of the President by Parliament (Bos, 2010: 81-82). Even so, 
after the leak of the information, Yanukovich announced the suspension of negotiations with BYuT and spoke of the need for the popular election of the president.

The constitutional process per se shows not the 'rule by law', but the lack of the 'rule of law'. Another indicator of such a deficit could be the signing of political pacts $^{22}$ between the different actors. Before 2004, the political scene was full of informal pacts. The Orange Revolution by itself could be regarded as one such informal pact. Thus, there were at least three informal agreements negotiated between Yushchenko and other actors: the first with Kuchma in round-table negotiations, over permission to re-run the second round of the presidential elections; the second with the leader of the Socialists, whose political power was to support Yushchenko in the rerun; and the third with Yulia Tymoshenko, to appoint her Prime Minister.

After 2004, some of these pacts were formalised. Moreover, all political conflicts were resolved by such agreements, whether signed or informal. The most notable example is the resolution of the political crises of 2007, when a long stand-off ended with the signing of the agreement ${ }^{23}$ by all forces to hold early parliamentary elections in September 2007. Other examples of signed pacts between elites are the 'Memorandum of Understanding between the Government and the Opposition' (the Memorandum), from September 2005; and the 'Universal of National Unity' (the Universal), ${ }^{24}$ from August 2006.

At first glance, the formalisation of political pacts in Ukraine could be regarded as a positive development. Yet these pacts did not provide sanctions for the violation of their requirements and thus had no legal force. Moreover, the nature of these pacts is different from the one that transitologists view as embodying a move towards democracy. ${ }^{25}$ The Ukrainian elite pacts did not facilitate the establishment of an overall binding framework for action, but were a means of obtaining situational support with the aim of achieving short-term goals. The pacts signed were, therefore, a kind of political barter.

In the case of the Memorandum, the President gained the support of the Party of the Regions in order that Parliament would appoint his nominee as Prime Minister. In return, Yushchenko agreed not to persecute the opposition - an act that observers rated as granting immunity to the former functionaries of the Kuchma regime (Durkot, 2005). In the case of the Universal, Yanukovich, now the leader of the Party of the Regions, received informal assurances from the President and other actors over his appointment as Prime Minister. In return, he obliged that his government would work to implement

22 The author does not include coalition agreements in the political pacts described in these paragraphs. Unlike political pacts, coalition agreements are prescribed in law.

23 'Joint Statement by President of Ukraine, the Verkhovna Rada of Ukraine and Ukraine's Prime Minister' (in Ukrainian), 27 May 2007, available at: http://www.president.gov.ua/news/ 6344.html [last accessed on 22 June 2010].

24 'Universal of National Unity' (in Ukrainian), 3 August 2006, available at: http://www.president.gov.ua/done_img/files/universal0308.html [last accessed on 22 June 2010].

25 For instance, O'Donnell and Schmitter (1986: 37) define the elite pacts as 'An explicit, but not always publicly explicated or justified, agreement among a select set of actors which seeks to define (or, better, to re-define) rules governing the exercise of power on the basis of mutual guarantees for the 'vital interest' of those entering into it'. 
the programme agreed in the Universal, which contained many items important to the President. ${ }^{26}$ Moreover, it was informally agreed that Parliament would appoint five pro-presidential ministers, in addition to the Ministers of Defence and Foreign Affairs whom the President would nominate according to the Constitution (Pleines, 2007b: 2; Whitmore, 2007: 3).

'Rule by law' could be understood, as already mentioned, as the usage of formal rules, often in their violation, to improve one's own position. Striking examples are the interpretations of the Constitution by actors in their own favour, facilitated by the unclear divisions of powers and the gaps in the Constitution itself. Back in 2005, the European Commission for Democracy through Law, better known as the Venice Commission, pointed to a number of such shortcomings in the Constitution and proposed ways of overcoming them. ${ }^{27}$ Yet none of its recommendations were ever implemented; moreover, most of its warnings came true. For instance, the Venice Commission warned that the overlapping competencies in the foreign and security spheres might become the source of future conflicts between the President and the government. And indeed, between December 2006 and March 2007 there was a strong collision between the Yanukovich coalition and the President around the dismissal of the pro-presidential Minister of Foreign Affairs. The conflict deepened further due to the Constitution making no explicit statement about what would happen if Parliament refused to accept the presidential nominee (Pleines, 2007b: 4). In February-March 2007, the President twice nominated a new Minister for Foreign Affairs, but both times Parliament refused to appoint the President's nominee. The result was that the country practically had no minister of foreign affairs for four months during 2006-2007. ${ }^{28}$

Another common practice in the 'rule by law' is a law drafted explicitly in one's own favour. A striking example of this could be the struggle over the law on the Cabinet of Ministers (the Cabinet law). Until 2006, the Cabinet of Ministers acted de facto without a law defining its organisation, powers and procedures. The Verkhovna Rada adopted it many times but, each time, President Leonid Kuchma used his veto and refused to sign it. The situation changed in December 2006, when the Yanukovich coalition, together with BYuT, managed to override the President's veto. After the President refused to sign it, the Cabinet law entered into force in January 2007, with the signature of the speaker of the parliament ${ }^{29}$ (Pleines, 2007b: 4; Tiede and Simon, 2008: 2).

26 Such as, for instance, the questions of the official language and integration into the EU and NATO. Yet, eventually, many disputed items were formulated in the version advocated by the Party of the Regions.

27 Venice Commission (2005) 'Opinion On The Amendments To The Constitution Of Ukraine Adopted On 8.12.2004' 13 June 2005, available at: http://www.venice.coe.int/docs/2005/ CDL-AD(2005)015-e.pdf [last accessed on 22 June 2010].

28 During this period, there were two acting ministers, one after another. However, acting ministers do not have the same level of responsibility as an appointed minister.

29 Before 2004, all laws had to be signed by the President in order to enter into force. Kuchma often used the practice of non-signing, making null and void those laws overridden in this way. Yet, according to the constitutional changes of 2004, if the President refuses to sign an 
The new Cabinet law saw an enormous shift of powers in favour of the Prime Minister - at that time, Yanukovich. Its many provisions newly regulated spheres that were determined by the Constitution. For instance, the President's nomination rights were limited by the introduction of a fifteen-day period during which the President must make nominations. The result was that many presidential powers were curtailed even without the constitutional changes. No wonder that the President opposed the adoption of the Cabinet law so vigorously - in December 2006, Yushchenko used his veto in general eight times; indeed, each time Parliament adopted it.

Even so, the struggle over the Cabinet law did not end in December 2006. In May 2008, Parliament adopted a new law on the Cabinet of Ministers,${ }^{30}$ which invalidated the previous version. Yushchenko was the initiator of the law-making process and so he tailored the Cabinet law according to his interests. With some amendments, the adopted law was, nevertheless, largely based on the President's draft. ${ }^{31}$ It limited the powers of the Prime Minister and strengthened those of the President. ${ }^{32}$ Once more, the powers of the ordinary person were expanded without any constitutional amendments.

'Rule by law' also means that the judiciary is not as independent a body as it should be; the courts become part of the political struggle and often pass politically motivated sentences. Unfortunately, the Constitutional Court of Ukraine has always been a pawn in elite power struggles. That two-thirds of the constitutional judges are appointed by the President and Parliament led to attempts by some politicians to influence the composition of the Constitutional Court to their own advantage. Before 2004 this was manifest, for instance, when the Constitutional Court allowed President Leonid Kuchma to run for a third term (Pleines, 2007a).

After the Orange Revolution, this practice did not disappear. In October 2005, the tenure of the many judges of the Constitutional Court of Ukraine appointed in 1996 came to an end. However, Parliament blocked the appointment of new judges, fearing that the new composition of the Constitutional Court could review the 2004 constitutional amendments. Consequently, the Constitutional Court was paralysed for almost the whole year. Only in August 2006, subsequent to the signing of the 'Universal of National Unity', did the new government coalition led by Viktor Yanukovich agree to appoint the judges. Even so, Parliament immediately adopted a clearly unconstitutional law that prohibited the Constitutional Court from reviewing the constitutionality of the 2004 constitutional reforms (Pleines, 2007a: 7). Moreover, the President signed this law, as it was agreed informally during negotiations on the Universal of National Unity.

overturned bill, it could be signed by the speaker of the parliament (Bredies, 2009: 35; Article 94, para. 4 of the constitution).

30 Law № 279-VI 'On the Cabinet of Ministers of Ukraine’ (in Ukrainian), 16 May 2008, available at: http://zakon.rada.gov.ua/cgi-bin/laws/main.cgi?nreg=279-17 [last accessed on 22 June 2010].

31 On the President's draft of the law on the Cabinet of Ministers, see Tiede and Simon (2008).

32 It seriously undermined the position of the Prime Minister, at that time Tymoshenko, but the Prime Minister's faction BYuT voted for the new Cabinet law in full, because this had been envisaged in the coalition agreement signed between the pro-presidential faction NUNS and Tymoshenko's BYuT in December 2007. 
The politicisation of the Constitutional Court reached its peak during the political crises of 2007. On 2 April 2007, President Yushchenko issued a presidential decree dissolving Parliament and calling for early elections. ${ }^{33}$ The representatives refused to obey the decree and immediately appealed to the Constitutional Court. The decree did not have a sound constitutional basis, ${ }^{34}$ so there was a threat to Yushchenko that the Constitutional Court could pass a verdict which was not in his favour (Wolowski, 2008: 32). From the beginning of the conflict, there was a pressure on the judges of the Constitutional Court from all parties. However, Yushchenko attempted first to compromise with Prime Minister Yanukovich and his coalition. The Constitutional Court even took a one week recess on 10 April. No agreement was reached between the President and the Prime Minister, so Yushchenko changed his tactics and the Constitutional Court became the main 'battlefield'.

On 16 April, the Security Service of Ukraine, linked to the President, accused the rapporteur for corruption. Yet, the loyal to the government Prosecutor General refused to bring charges against the rapporteur (Wolowski, 2008: 31). On 30 April, 1 May and 10 May, he issued decrees to dismiss three Constitutional Court judges, one of whom was the rapporteur. However, the judges did not obey and a war in court followed. According to Wolowski (2008: 32), there were in total twelve judgments passed by various common courts between 16 and 25 May, six of which approved the dismissal of the Constitutional Court judges while the other six did not. However, the dismissed judges appealed to the Prosecutor General, whose decision to side with the judges saw him fired by Yushchenko on 24 May. The next day, the pro-Yanukovich Minister of Interior Affairs attempted to seize the General Prosecutor's office with the help of armed men. In return, Yushchenko signed a decree to take control of the interior troops. There was now a real threat that an armed conflict could take place. Only after that did the parties start to negotiate.

After a stand-off lasting almost two months, the political conflict was resolved not by means of the Constitutional Court but by a political agreement between the President, the Prime Minister and the Parliament Speaker.

The political crises of 2007 could be a 'classical' example of 'rule by law'. After 2007, the most striking examples of the instrumentalisation of the Constitutional Court are the decisions of the Court on the principles of coalition-building. The departure of the pro-presidential faction NUNS from the coalition of Orange forces in September 2008 led the Constitutional Court to rule that only factions can form a coalition in Parliament. ${ }^{35}$ This decision was especially favourable to Tymoshenko, when her coalition did not de facto have sufficient voices to adopt laws but which de jure continued to exist. However, when Viktor Yanukovich was elected President, the Constitutional

33 He was prompted to do so since, in March 2007, individual representatives from opposition factions started joining Yanukovich's coalition. This posed a threat that the ruling coalition might garner sufficient votes to amend the constitution to the president's disadvantage.

34 It did not fall under any of the three cases that grant the President the right to dismiss Parliament. See Article 90 of the constitution of Ukraine.

35 Decision of the Constitutional Court of Ukraine, Case No. 1-40/2008 (in Ukrainian), 17 September 2008, available at: http://zakon.rada.gov.ua/cgi-bin/laws/main.cgi?nreg=v016p7 10-08 [last accessed on 22 June 2010]. 
Court delivered a quite different judgment. In April 2010, it ruled that not only factions but also representatives who are not members of factions could form a coalition. ${ }^{36}$ Thus, the practice which Yanukovich had used in 2007 and which had triggered the acute political conflict, became legitimised. The result was that some deputies left their factions and the pro-presidential coalition grew.

\section{Understanding political change in Ukraine in 2005-2010}

Considering Ukraine as a neo-patrimonial state opens a different path for reviewing the political changes of the last five years. In this respect, the approaches introduced here - oligarchic-patrimonialism and patronal presidentialism - could prove to be useful for the analysis of post-revolutionary Ukraine as well. Their analytical utility in understanding the political change in Ukraine since 2005 is, however, limited. Therefore another approach has to be developed.

The first approach - oligarchic-patrimonialism - stays relevant for the study of postrevolutionary Ukraine, because Ukrainian oligarchs maintained their political influence after the Orange Revolution as well. Many scholars emphasise that the main promise of the Orange Revolution 'to send the bandits to jail' was never delivered: not one of those suspected of corruption during the Kuchma regime was ever charged or convicted (Simon, 2009; Lindner, 2006; Pleines, 2009; Puglisi, 2008). In October 2005, the socalled 'Council of the Oligarchs' had already taken place, with the participation of twenty leading entrepreneurs (Puglisi, 2008: 61).

After Yushchenko was elected President, the 'oligarchical' landscape changed (Pleines, 2009: 113). Some oligarchs with close ties to Kuchma left politics; others switched sides. What is important is that, since 2005, they began to support different political forces (Pleines, 2010). All in all, the 'oligarchisation' of Parliament stayed a characteristic feature of the Ukrainian parliamentary system under Yushchenko as well, although after two parliamentary elections their number had somewhat decreased. ${ }^{37}$ Thus, another promise of the Orange Revolution - the separation of big business and politics - was fulfilled. The only actions that the Orange government had successfully conducted against oligarchs during the last five years was the re-privatisation of the steel giant Kryvorizhstal ${ }^{38}$ in October 2005 (Puglisi, 2008: 60; Pleines, 2010: 132); and

36 Decision of the Constitutional Court of Ukraine, Case No. 1-33/2010 (in Ukrainian), 6 April 2010, available at: http://zakon.rada.gov.ua/cgi-bin/laws/main.cgi?nreg=v011p710-10 [last accessed on 22 June 2010].

37 Pleines (2009: 113) lists the following numbers - twelve oligarchs in Parliament at the beginning of 2006; ten after the parliamentary elections in March 2006; and eight after the preliminary elections in September 2007. The declining numbers are due to many oligarchs now preferring to have their cronies in Parliament. Thus have oligarchs expanded their patronage networks.

38 The plant was privatised in 2004 by Rinat Akhmetov, Viktor Yanukovich's main financial supporter during the presidential elections of 2004, and Viktor Pinchuk, President Kuchma's son-in-law. 
the elimination of the dubious intermediary firm Ukrgazenergo from the gas trade between Russia and Ukraine as a result of the second gas war in January 2009. ${ }^{39}$

Recently, a number of scholars have begun to underline the democratising role of the oligarchs (Melnykovska and Schweickert, 2008; Puglisi, 2008). Having accumulated their wealth in a dubious way, some oligarchs are now seeking legitimisation via establishing different charity funds, or maintaining frequent contacts with western politicians and business leaders. In addition, some oligarchs are now actively involved in the promotion of Ukraine's integration into the EU. This strategy kills two birds with one stone - integration into the EU should help facilitate access to western markets and, at the same time, increase the level of protection of property rights in Ukraine, thus securing the oligarchs' positions. In this way, the Orange Revolution in general, and the re-privatisation campaign of 2005 in particular, had a positive impact on the role of the oligarchs in Ukrainian politics - a phenomenon that Pleines (2010) calls 'democratization without democrats'.

However, there are also a number of deterrents to such a path to democracy. First, as Pleines indicates, oligarchs seek only economic, but not political, integration with the EU. The neo-patrimonial character of the Ukrainian state would, therefore, stay practically unchanged. Second, the global financial crisis has seriously hit the financial positions of the oligarchs and has made them once more dependent on preferential handling by the state.

At first glance, the second approach - 'patronal presidentialism' - might be regarded as irrelevant in understanding the political changes in Ukraine after the Orange Revolution. Indeed, after the constitutional reform of 2004, the constitutional basis of patronal presidentialism was significantly undermined. However, even after that, Ukraine remained a semi-presidential republic. Taking into consideration the neo-patrimonial character of Ukraine, the role of the president depends in the first place not on the powers that the office formally possesses, but on the current constellation of powers. This leads to a modification of Hale's concept: we should place as an independent variable not institutional design, but the power imbalance characterised not only by formal, but also informal, resources, as well as actors' expectations or assessments of other actors' possible behaviour.

The ideas of the imbalance in powers and the expectations of actors could be found in a part of Hale's concept that has not yet been described. The main goal that Hale pursued with his concept was not to depict the regime under Kuchma, but to explain the phenomenon of the Orange Revolution. According to Hale, the institutional design of patronal presidentialism predetermines the cyclical phases of elite consolidation and contestation. The Orange Revolution is, namely, such a cyclical change from consoli-

39 This firm partly belonged to the oligarch Dmytro Firtash. Yet, with the election of Viktor Yanukovich as President of Ukraine in February 2010, Firtash started to strengthen his position again. 
dation to contestation. The trigger for this transition is identified by Hale as 'lame duck syndrome' which:

Precipitates elite defection from the incumbent president's team when elites believe the incumbent may leave office. (Hale, 2005: 135) (0 $^{40}$

Based on the considerations above, political change in Ukraine during 2005-2010 could be explained by the following model, which is based on three assumptions. The first of these is that politics in Ukraine is highly competitive and is marked by shortterm goals. The second assumption is that Ukrainian politics has a zero-sum or 'winnertakes-all' character (what one actor gains, other actors lose). The third assumption is that Ukraine is a neo-patrimonial state, in which the personification of politics is high and actors' behaviour is guided by both formal and informal logics. Thus, our model looks as follows:

Political change $=$ Power imbalance $\{$ Formal resources + Informal resources + Actors' expectations\}

Formal resources derive directly from the formal positions of the actors and are more or less defined. Actors' informal resources are, on the one hand, dependent on formal posts, but could be enhanced via co-operation with other actors (for instance, via patronage networks). Actors' expectations of the behaviour of other actors are based on the personality of the actor and his or her preferred way of action. Now we can test our model.

One of the main consequences of the Orange Revolution was the multiplication of actors competing for power, as well as of access points to power (Puglisi, 2008: 63; D'Anieri, 2007: 214). This had already led to the enormous power imbalance in 2005. Also actors' expectations of the behaviour of other actors changed. It was expected that the Orange forces, represented in the first place by President Viktor Yushchenko and Prime Minister Yulia Tymoshenko, would behave more democratically and in compliance with formal rules.

The constitutional amendments of 2004 that entered into force in 2006 led not only to a redistribution of formal resources but also of informal ones. D'Anieri (2007: 214) suggests that the President, on the one hand, retained both some ability to use selective law enforcement by further controlling powerful ministries, as well as some patronage power via the appointment of regional governors. On the other hand, the Prime Minister got much of the power of the 'rule by law' that Kuchma had. Moreover, as Parliament was turned into a powerful formal institution, the formal and informal powers of those actors who had a well-consolidated party and a well-managed patronage network increased. The latter could be said especially about the Party of the Regions, which was, in comparison to other factions, more united, better organised and had a good voter base. However, each time the Party of the Regions tried to concentrate power in its

40 Even so, Hale did not specify in his work how the reverse process - a change from contestation to consolidation - occurs. 
hands, the actors' fears or expectations of more authoritarian behaviour that could undermine their positions consolidated the opposing forces. Thus, during the whole of Yushchenko's time in office, there was no balance of power, which led to a permanent political crisis.

The application of this model for analysing Ukrainian politics after the presidential elections of 2010 needs some modification. Enjoying from the beginning quite a significant parliamentary support from his Party of the Regions (it is, at this time, the largest faction in Parliament), President Viktor Yanukovich has combined his formal powers as President with the formal powers of Parliament. This had a multiplication effect on actors' expectations. Perceiving the President and his coalition as a dominant power, the actors began moving to his side. This, in turn, led to the multiplication of the informal powers of the President. Thus, the model still can explain political change in Ukraine after the presidential elections. However, depending on the situation, the combination of variables leads not to a power imbalance, but has a multiplying effect leading to power dominance.

\section{References}

Baum C, M. Caglayan and D. Schäfer (2008) Political patronage in Ukrainian banking DIW Berlin.

Bos, E (2010) 'Stabile Instabilität, dynamische Blockade. Das politische System der Ukraine und seine Defekte’ Osteuropa 60(2-4): 77-88.

Bratton, M and N. van de Walle (1994) 'Neopatrimonial regimes and political transitions in Africa' World Politics 46(4): 453-89.

Bredies, I (2009) 'The 2004 Constitutional Reform. Origins, Driving Forces and Consequences' in J. Besters-Dilger (Ed.) Ukraine on Its Way to Europe. Interim Results of the Orange Revolution Frankfurt: Peter Lang Verlag, pp. 27-43.

Carothers, T (2002) 'The end of the transition paradigm' Journal of Democracy 13(1): $5-21$.

D'Anieri, P (2007) Understanding Ukrainian politics: power, politics and institutional design ME Sharpe.

Darden, K (2001) 'Blackmail as a tool of state domination: Ukraine under Kuchma' East European Constitutional Review 10(2-3): 67-71.

Durkot, J (2005) 'Ukraine. Die durchwachsene Bilanz für "Orange"' $K A S-A I, H$ 12: 151-67.

Erdmann, G and U. Engel (2006) Neopatrimonialism revisited: beyond a catch-all concept GIGA Working Papers No. 16.

Fischer, S, R. Puglisi, K. Wolczuk and P. Wolowski (Eds.) (2008) Ukraine: quo vadis? Institute for Security Studies, European Union, Chaillot Paper No. 108.

Fisun, A (2007) 'Postsovetskie neopatrimonial'nye rezhimy: genezis, osobennosti, tipologija' Otechestvennye zapiski 6. 
Franke, A, A. Gawrich and G. Alakbarov (2009) 'Kazakhstan and Azerbaijan as PostSoviet Rentier States: Resource Incomes and Autocracy as a Double "Curse" in Post-Soviet Regimes' Europe-Asia Studies 61(1): 109-40.

Hale, H (2005) 'Regime Cycles. Democracy, Autocracy, and Revolution in Post-Soviet Eurasia' World Politics 58(1): 133-65.

Hale, H (2006) 'Democracy or autocracy on the march? The colored revolutions as normal dynamics of patronal presidentialism' Communist and Post-Communist Studies 39(3): 305-29.

Hensell, S (2009) Die Willkür des Staates: Herrschaft und Verwaltung in Osteuropa Wiesbaden: VS Verlag.

Ilkhamov, A (2007) 'Neo-patrimonialism, interest groups and patronage networks: the impasses of the governance system in Uzbekistan' Central Asian Survey 26(1): 65-84.

Isaacs, R (2010) 'Informal politics and the uncertain context of transition: revisiting early stage non-democratic development in Kazakhstan' Democratization 17(1): $1-25$.

Kowall, T and K. Zimmer (2002) 'Der politische Einfluß von Wirtschaftseliten in der Ukraine. Nationale und regionale Oligarchen’ Arbeitspapiere der Forschungsstelle Osteuropa 42, Bremen.

Kusznir, J and H. Pleines (2006) 'Informal Networks in Ukraine's Privatisation Auctions' in KICES Working Papers 6: 37-51.

Lange, N (2009) 'Die politische Dauerkrise und Probleme der ukrainischen Verfassungsordnung' Ukraine-Analysen 64: 2-8.

Lange, N (2010) The first 100 Days after Change of Power in Ukraine: Authoritarian Tendencies and Rapprochement with Russia KAS Country Report.

Lindner, R (2006) 'Das Ende von Orange. Die Ukraine in der Transformationskrise' SWP-Studie p. 20, Berlin.

Melnykovska, I and R. Schweickert (2008) 'Who You Gonna Call? Oligarchic Clans as a Bottom-Up Force of Neighborhood Europeanization in Ukraine' Arbeitspapiere des Osteuropa-Instituts 67/2008, FU Berlin.

O'Donnell, G (1996) 'Illusions about consolidation' Journal of Democracy 7: 34-51.

O'Donnell, G and P. Schmitter (1986) Transitions from authoritarian rule: Tentative conclusions about uncertain democracies Johns Hopkins University Press.

Pitcher, A, M. Moran and M. Johnston (2009) 'Rethinking Patrimonialism and Neopatrimonialism in Africa' African Studies Review 52(1): 125-56.

Pleines, H (2005) Ukrainische Seilschaften: informelle Einflussnahme in der ukrainischen Wirtschaftspolitik, 1992-2004 LIT Verlag: Münster.

Pleines, H (2007a) 'Das ukrainische Verfassungsgericht' Ukraine-Analysen 26: 7-8. 
Pleines, H (2007b) 'Der politische Machtkampf in der Ukraine. Kurzsichtigkeit mit langfristigen Folgen' Ukraine-Analysen 21: 2-6.

Pleines, H (2009) 'The Political Role of the Oligarchs' In J. Besters-Dilger (Ed.) Ukraine on Its Way to Europe. Interim Results of the Orange Revolution Frankfurt: Peter Lang Verlag, pp. 103-19.

Pleines, H (2010) 'Demokratisierung ohne Demokraten. Die Oligarchen in der ukrainischen Politik’ Osteuropa 60(2-4): 123-34.

Przeworski, A (1991) Democracy and the market: Political and economic reforms in Eastern Europe and Latin America Cambridge University Press.

Puglisi, R (2003) 'The rise of the Ukrainian oligarchs' Democratization 10(3): 99-123.

Puglisi, R (2008) 'A window to the world? Oligarchs and foreign policy in Ukraine' in S Fischer, R Puglisi, K Wolczuk and P Wolowski (Eds.) Ukraine: quo vadis? Institute for Security Studies, European Union, pp 55-86.

Razumkov Centre (2009) 'Political corruption in Ukraine: potential actors, areas, manifestations, trends' National Security \& Defence 7/2009, Kyiv.

Simon, G (2009) 'After the Orange Revolution: the Rocky Road to Democracy' in J. Besters-Dilger (Ed.) Ukraine on Its Way to Europe. Interim Results of the Orange Revolution Frankfurt: Peter Lang Verlag, pp.13-26.

Starr, F (2006) 'Clans, Authoritarian Rulers and Parliaments in Central Asia' Silk Road Paper John Hopkins University.

Tiede, W and C. Simon (2008) Das ukrainische Kabinettsgesetz Ukraine-Analysen 37: $2-5$.

Weber, M, G. Roth and C. Wittich (Eds.) (1978) Economy and society: An outline of interpretive sociology University of California Press.

Whitmore, S (2007) 'Man spielt mit den Regeln und nicht nach den Regeln. Politische Ungewissheit in der Ukraine’ Ukraine-Analysen 19: 2-5.

Wolowski, P (2008) 'Ukrainian politics after the Orange Revolution - How far from democratic consolidation?' in S Fischer, R Puglisi, K Wolczuk and P Wolowski (Eds.) Ukraine: quo vadis? Institute for Security Studies, European Union, pp. 25-53.

Zimmer, K (2005) 'Klientelismus im neopatrimonialen Staat. Regionale Machtsicherung in der Ukraine' Osteuropa 55(10): 59-73.

Zimmer, K (2006) Machteliten im ukrainischen Donbass. Bedingungen und Konsequenzen der Transformation einer alten Industrieregion Berlin: LIT-Verlag.

Zimmer, K (2008) 'Formal institutions and informal politics in Ukraine' in G. Meyer (Ed.) Formal Institutions and Informal Politics in Central and Eastern Europe: Hungary, Poland, Russia and Ukraine Opladen: Barbara Budrich Esser, 2nd Ed. pp. 267-313. 